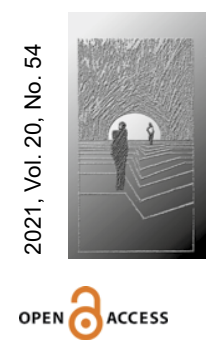

\title{
Editorial: \\ Care and upbringing in times of crisis
}

\section{Ladies and Gentlemen,}

The current issue of our journal is devoted to the widely recognized issue of care and upbringing in times of crisis.

Care and upbringing appear to be the inseparable forms of activity of every human being, especially those who realize their vocation in the family life. We usually talk about care in the parent - child, child - parent, guardian - ward, doctor - patient relationship. Care is often associated with upbringing.

Both forms of human activity - care and upbringing - require from the people engaged in their performing - effort, sacrifice, time, energy, financial resources, and other elements necessary for their proper course. Favourable living conditions for fulfilling these forms of human activity do not free from the hardships inherent in their implementation. When an unplanned crisis situation occurs, the burden of caring of another person and raising children increases, and sometimes it may turn out to be the burden that is too difficult to bear for a particular person. The circumstances that may constitute crisis situations are circumstances that may affect both individuals and entire communities, societies or even the entire world.

In the current issue of 'Horizons of Education' you will find papers on issues relating to: comparative legal analysis of post-divorce parental agreements regarding child custody; the child's right to a personal relationship with separated parents; the role of the family in the process of human development; the organization and course of the education and care process for schoolchildren during the SARS-CoV-2 virus pandemic in Poland; online teaching method in the context of educational and therapeutic progress of a child with specific learning difficulties; the daily life of contemporary mothers - between social expectations, the sense of duty and the individual experience of motherhood; lawdemic, or the legal reality in the era of the pandemic in Poland; the migration crisis and the global migration management system in the situation of the COVID-19 pandemic.

On behalf of the entire Editorial Board I wish you an enjoyable and beneficial read. 